\title{
Groundwater Quality in the Wassa West District of the Western Region of Ghana
}

\author{
B. K. Kortatsi \\ CSIR-Water Research Institute, P. O. Box M.32, Accra, Ghana
}

\begin{abstract}
Reconnaissance hydrochemical survey of 56 wells was conducted in the Wassa West District with the objective of providing baseline data for the establishment of groundwater quality monitoring stations. The data acquired is used in this paper to assess the quality of groundwater in the District. Groundwaters are mainly mildly aggressive with $p \mathrm{H}$ values in the range 4.5-6.9. However, a few of the boreholes show strong acidic character ( $p \mathrm{H}$ range 3.7-4.0). The conductivity values are in the range $37-780 \mu \mathrm{S} \mathrm{cm}-1$ with a mean $246.4 \mu \mathrm{S} \mathrm{cm} \mathrm{cm}^{-1}$ suggesting the groundwaters are generally fresh and have short residence time. The groundwaters are moderately hard to very hard with only $40 \%$ of the samples representing soft waters. Groundwater quality is excellent with respect to major ions $\left(\mathrm{Ca}^{2+}, \mathrm{Mg}^{2+}, \mathrm{Na}^{+}, \mathrm{HCO}_{3}\right.$, $\mathrm{SO}_{4}^{2-}, \mathrm{Cl}^{-}$) as they fall below their respective WHO guideline limits for water potability. Uncharacteristic of mining areas, trace metals loading of the groundwaters are generally low. All except aluminum, arsenic, barium, iron, manganese, mercury and nickel have concentrations well below the WHO guideline limits for water potability. Aluminum (0.0-2.5 mg 1-1), iron (0.0-18.3 $\left.\mathrm{mg} \mathrm{l}^{-1}\right)$ and manganese $\left(0.0-2.41 \mathrm{mg} \mathrm{l}^{-1}\right)$ are higher than WHO guideline limits of $0.2 \mathrm{mg} \mathrm{l}^{-1}, 0.3 \mathrm{mg} \mathrm{l}^{-1}$ and $0.5 \mathrm{mg} \mathrm{l}^{-1}$ in more than $20 \%, 40 \%$ and $25 \%$ of the wells, respectively, and, therefore, pose significant aesthetic quality problems to groundwater quality. Mercury concentration exceeds the WHO guideline limit of $0.001 \mathrm{mg} \mathrm{l}^{-1}$ in all the wells during the rainy season and, thus, poses the greatest physiological threat for groundwater usage for drinking purposes in the District. Arsenic and barium exceeded the WHO guideline limit in less than $5 \%$ of the wells. Aesthetic problems can be eliminated using iron removal plants or aerators. These will induce the co-precipitation of trace metals with ferric oxyhydroxide. Limiting mercury usage in mining will curtail physiological problems.
\end{abstract}

\section{Introduction}

Wassa West District extends approximately from $1^{0} 54^{1}$ to $2^{0} 11^{1} \mathrm{~W}$ and from $5^{0} 06^{1}$ to $5^{0} 35^{1} \mathrm{~N}$ (Fig. 1). It lies along the main gold belt of Ghana that stretches northeastwards from Axim in the southwest to Agogo in the northeast (Marston et al., 1993; Agyapong et al., 1993; Acquah, 1992) and, thus, one of the main gold mining districts of Ghana. Gold is not the only mineral mined in this District. The main manganese mines in Ghana, as well as some diamond mines, are also found in the District (Appiah et al., 1993). Thus, the District is socio-economically very important to Ghana. 


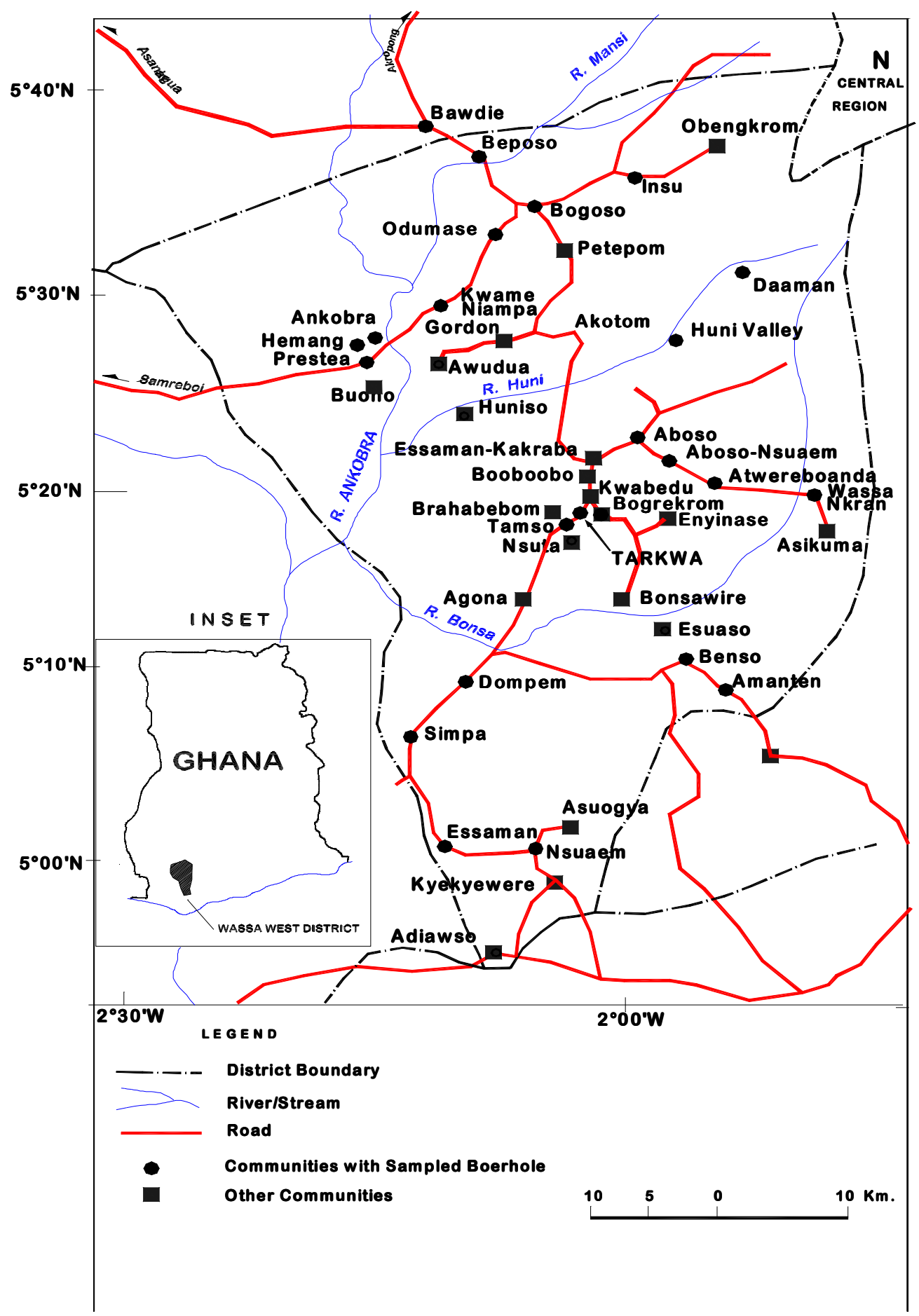

Fig. 1. Location map of the Wassa West District showing the sampling locations

Surface waters (rivers and streams) used to be the main source of drinking water in the District. However, recent studies have shown that most of the surface waters are polluted and unsafe for drinking purposes as a result of the intense mining activities. For instance, River Ankobra that is the major river that drains the District is regarded dead due to its high level of pollution (WRRI, 1986). Increasingly realising that the surface waters are somewhat polluted, the 
Government of Ghana and some major mining companies operating in the District provide boreholes as alternative source of drinking water. The number of boreholes and hand-dug wells keep increasing annually to the extent that groundwater is becoming the principal and sometimes the only source of drinking water for the communities within the Wassa West District.

The increasing groundwater usage is based on the postulation that groundwater being precluded from the atmosphere is less susceptible to pollution. This is true to some extent. However, groundwaters in hard-rock aquifers, particularly in mining areas, are known to be vulnerable to quality problems that may have serious impact on human health. The rocks are often carbonate-deficient and give rise to poorly buffered water (Smedley et al., 1995). Acid rain or $\mathrm{CO}_{2}$ waters may encourage dissolution of elements such as $\mathrm{Al}, \mathrm{Mn}, \mathrm{Be}$, and Fe from most host rocks. For instance, Wilson \& Hawkins (1978) observed concentrations of As between $240 \mu \mathrm{g} \mathrm{l}^{-1}$ and $1.2 \mathrm{mgl}^{-1}$ in the Fairbanks area, Alaska. Similarly, William \& Smith (1994) reported acid waters draining a gold mining area in Zimbabwe as having As concentration of up to $72 \mathrm{mgl}^{-1}$.

Smedley et al. (1995) stated that many hard rock aquifers contain sulphide minerals particularly in their vein complexes that may include high concentrations of other toxic metals such as $\mathrm{As}, \mathrm{Sb}, \mathrm{Pb}$ and $\mathrm{Ba}$. Oxidation of the sulphides may lead to the release of high concentrations of these metals into the groundwater and render it potentially dangerous. They went on to state that the occurrence of arsenic in high concentrations would be associated with manganese and iron ores especially sulphide minerals such as pyrites. The main gold ore associated with the Birimian is refractory quartz-Fe/As sulphide lode gold (Marston et al., 1993). Junner et al. (1942) pointed out that pyrite is common in many of the igneous rocks and quartz veins that intruded the Birimian and the Tarkwaian rocks in the area. Thus, there is the high probability of trace metal pollution of the groundwaters in the Wassa West District particularly the Birimian rock areas. It is against this background that the paper seeks to examine the physicochemical quality of groundwater in the Wassa West District.

\section{Physical settings of the study area}

The Wassa West District is underlain by the lower Proterozoic rocks divided into the Birimian and Tarkwaian system. The Birimian system is unconformably overlain by the Tarkwaian system. Sills and dykes of igneous rocks ranging from felsite and quartz porphyry to meta-dolerite, gabbro and norite intrude into the Birimian and the Tarkwaian system at several places (Junner et al., 1942). Geomorphologically, the Wassa West District is highly dissected and reduced to uniformly moderate relief with a gentle slope to the south. The mean annual rainfall is between 1450 and $2600 \mathrm{~mm}$. The highest mean monthly temperature is approximately $30^{\circ} \mathrm{C}$ and occurs between March and April whereas the lowest temperature is approximately $26^{\circ} \mathrm{C}$. This occurs in August (Dickson \& Benneh, 1980). The vegetation of the District consists partly of the tropical rain forest and partly of the moist semi-deciduous forest. The tropical rain forest occurs in the southwest while the moist semi-deciduous forest covers the remaining portion.

\section{Materials and methods}

Water samples were collected from both hand-dug wells and boreholes used for drinking purposes in the Wassa West District. In all, about 56 water points were sampled. At each sampling site, two samples were collected, one for metals and the other for anions analyses. Each sample was collected in $100 \mathrm{ml}$ acid-washed high-density linear polyethylene (HPDE) bottles with strict adherence to the sampling protocol described by Claasen (1982) and Barcelona et al. (1985). To remove particulate matter from samples, filtering was performed using a Sartorius polycarbonate filtering apparatus and a $0.45-\mu \mathrm{m}$ cellulose acetate filter membrane. The sample meant for metal analyses was immediately acidified to a $p \mathrm{H}<2$ after filtration using reagent grade nitric acid while those for anion analyses were without preservation. 
On-site analyses of temperature, redox potential (Eh), $p \mathrm{H}$ and electrical conductivity were conducted using WTW-Multiline P4 Universal Meter in an anaerobic flow-through cell attached in line to the borehole pump outlet. Prior to these analyses, pumping was carried out until stable meter readings for these parameters $(p \mathrm{H}, \mathrm{Eh}$, etc.) were obtained. This was to avoid the sampling of annulus water that would be in the pump and pump systems. Since the boreholes were consistently in use, mean time for clear pumping before sample taking was 5 min. Alkalinity titration was carried out at the wellhead using HACH Digital Titrator Model 16900. All major ions $\left(\mathrm{Na}^{+}, \mathrm{K}^{+}, \mathrm{Ca}^{++}, \mathrm{Mg}^{++}, \mathrm{HCO}_{3}^{-}, \mathrm{Cl}-, \mathrm{SO}_{4}^{2}{ }^{2}\right)$, as well as some trace elements, such as $\mathrm{NO}_{3}^{-}$, and F-, were analysed using Dionex DX-120 ion chromatograph at the Ecological Laboratory, University of Ghana. The analysis of all trace metals was also carried out using ICP-MS at the Geological Institute of the University of Copenhagen, Denmark. The ionic balance for the analyses varied from $-3.0 \%$ to $10.8 \%$. However, more than $85 \%$ of the analyses have ionic balance within $\pm 5 \%$. Ionic balance outside $\pm 5 \%$ is largely associated with samples with very low conductivity values (total dissolved solids).

\section{Results and discussion}

Representative chemical data (major ions and selected trace metals) are presented in Table 1 . The results show that the ground-waters in the Wassa West District are generally within the $p \mathrm{H}$ range 4.5-6.9 indicating that the groundwaters are mildly acidic, probably derived from carbonic acid due to the dissolution of atmospheric $\mathrm{CO}_{2}$, or $\mathrm{CO}_{2}$ generated in the soil zone as a result of the oxidation of soil organic matter (Hounslow, 1995; Langmuir, 1997). There are, however, a few boreholes such as 44-I-45-4 and 20-I-89-1 at Odumase and Tamso (Fig.1), respectively, that have $p \mathrm{H}$ below 4.0 and, thus, indicate strong acidic character. Acidity increases the capacity of the water to attack geological materials and leach toxic trace metals into the water making it potentially harmful for human consumption. Thus, the moderate to strong acidity of the groundwaters suggests that the waters are susceptible to trace metal pollution if these metals are present in the rock matrix through which the water percolates.

TABLE 1

Major and minor ions data for representative groundwater samples from the Wassa West District

\begin{tabular}{|c|c|c|c|c|c|c|c|c|c|c|c|c|c|c|c|}
\hline Location & $\begin{array}{l}\text { BH No. } \\
\mathrm{Cl}\end{array}$ & $\begin{array}{l}\text { Temp } \\
\mathrm{NO}_{3}\end{array}$ & $\begin{array}{l}\mathrm{pH} \\
F\end{array}$ & $\begin{array}{l}\text { Cond. } \\
\mathrm{SiO}_{2}\end{array}$ & Alk. & $T H$ & $\mathrm{Ca}$ & $M g$ & $\mathrm{Na}$ & $K$ & $\mathrm{HCO}_{3}$ & $\mathrm{SO}_{4}$ & & & \\
\hline Prestea & Gwcc (13) & 27 & 5.58 & 210 & 104 & 64 & 12.8 & 7.8 & 15.8 & 0.4 & 127 & 0.0 & 23.8 & 3.2 & 0.05 \\
\hline Prestea & Gwcc (12) & 26.3 & 5.97 & 299 & 148 & 112 & 29.7 & 9.2 & 14.9 & 0.3 & 181 & 0.0 & 10.9 & 0.1 & 0.21 \\
\hline Hemang & $20-13-65-4$ & 27.4 & 5.37 & 257 & 52 & 58 & 7.2 & 9.7 & 18.1 & 1.6 & 63 & 5.5 & 28.8 & 5.6 & 0.1 \\
\hline Ankobra & 050302/B/065-2 & 26.8 & 5.74 & 180 & 76 & 52.0 & 14.5 & 3.8 & 12.5 & 0.2 & 93 & 0.0 & 7.0 & 1.0 & 0.4 \\
\hline Ankobra & 050302B/065-1 & 29.2 & 5.66 & 187 & 116 & 40 & 4.8 & 6.8 & 9.4 & 0.6 & 142 & 5.3 & 8.0 & 0.2 & 0.02 \\
\hline Kwame Nirmpa & $20-C-01-2$ & 27.3 & 5.85 & 339 & 116 & 114 & 36.1 & 5.8 & 19.1 & 0.3 & 142 & 17.3 & 30.8 & 0.8 & 0.02 \\
\hline Odumase & $44-\mathrm{I}-45-1$ & 26.8 & 5.7 & 169 & 100 & 36 & 7.2 & 4.4 & 12.2 & 0.2 & 122 & 0.0 & 8.9 & 0.1 & 0.03 \\
\hline Odumase & $44-I-45-4$ & 27.7 & 3.74 & 536 & 0 & 76 & 11.2 & 11.7 & 40.0 & 25.0 & 0 & 30.2 & 77.4 & 4.1 & 0.5 \\
\hline Beposo & 44-E-73-1 & 26.9 & 5.54 & 204 & 68 & 58 & 18.4 & 2.9 & 17.1 & 0.4 & 83 & 0.0 & 14.9 & 0.2 & 0.04 \\
\hline Beposo & 44-E-73-2 & 27.6 & 5.72 & 309 & 92 & 62 & 12.0 & 7.8 & 27.2 & 0.6 & 112 & 7.5 & 30.8 & 0.0 & 0.25 \\
\hline Dauranpong & $44-C-32-2$ & 26.7 & 5.5 & 105 & 80 & 32 & 4.8 & 4.9 & 11.2 & 0.3 & 98 & 0.0 & 2 & 0.9 & 0.06 \\
\hline Bogoso Clinic & $44-I-28-1$ & 27.3 & 5.75 & 188 & 92 & 76 & 23.3 & 4.3 & 8.1 & 0.1 & 112 & 0.0 & 6 & 0.8 & 0.0 \\
\hline Insu & $47-0-98-1$ & 27.4 & 5.58 & 330 & 48 & 92 & 27.3 & 5.8 & 20.8 & 3.3 & 59 & 5.0 & 39.7 & 2.7 & 0.03 \\
\hline Insu & $47-0-98-3$ & 26.1 & 6 & 251 & 80 & 90 & 24.9 & 6.7 & 15.7 & 0.9 & 98 & 0.0 & 23.8 & 0.1 & 0.04 \\
\hline Huni Valley & W 121 & 28.1 & 6.23 & 248 & 124 & 94 & 28.9 & 5.3 & 14.6 & 1.0 & 151 & 0.0 & 4 & 0.2 & 0.03 \\
\hline Aboso Nsuem & C1-D-090-1 & 27.5 & 6.64 & 780 & 320 & 358 & 115 & 16.9 & 21.7 & 9.6 & 390 & 19.2 & 53.6 & 11.0 & 0.05 \\
\hline Atwereboanda & C1-H-004-1 & 26.5 & 6.01 & 483 & 148 & 184 & 42.5 & 18.9 & 18.6 & 6.5 & 181 & 29.2 & 50.6 & 3.0 & 0.07 \\
\hline Atwereboanda & C1-H-004-2 & 26.4 & 5.94 & 213 & 80 & 78 & 21.6 & 5.8 & 12.8 & 3.5 & 98 & 12.5 & 8.9 & 0.0 & 0.05 \\
\hline Tarkwa Sec. Sch & Borehole & 26.4 & 6.34 & 572 & 276 & 282 & 105 & 4.7 & 15.7 & 1.2 & 337 & 5.0 & 11.9 & 1.0 & 0.0 \\
\hline Tamso & $20-1-89-2$ & 25.8 & 4.38 & 101 & 12 & 16 & 4.0 & 1.5 & 10.0 & 0.2 & 15 & 0.0 & 12.9 & 11 & 0.06 \\
\hline
\end{tabular}




\begin{tabular}{|c|c|c|c|c|c|c|c|c|c|c|c|c|c|c|c|}
\hline Tamso & $20-1-89-1$ & 26.3 & 3.77 & 230 & 0 & 18 & 4.0 & 1.9 & 21.8 & 2.7 & 0 & 0.0 & 32.8 & 10 & 0.0 \\
\hline Benso & $21-E-13-4$ & 26.7 & 4.57 & 66 & 36 & 28 & 4.8 & 3.9 & 7.0 & 1.6 & 44 & 0.0 & 6 & 3.4 & 0.0 \\
\hline Benso & 21-E-13-3 & 26.6 & 5.15 & 130 & 32 & 14 & 4.0 & 1.0 & 14.7 & 2.1 & 39 & 0.0 & 11.9 & 127 & 0.02 \\
\hline Nsuaem & D4-I-088-1 & 26.1 & 6.41 & 465 & 236 & 222 & 68.9 & 12.1 & 18.8 & 0.6 & 288 & 0.0 & 7 & 0.1 & 0.04 \\
\hline Nsuaem & $18-\mathrm{I}-58-3$ & 26.7 & 5.93 & 297 & 80 & 98 & 24.9 & 8.7 & 17.9 & 0.6 & 98 & 0.0 & 32.8 & 3.2 & 0.03 \\
\hline Simpa & 18-E-77-3 & 27.1 & 5.79 & 648 & 120 & 202 & 59.3 & 13.1 & 36.0 & 3.1 & 146 & 17.9 & 110 & 0.0 & 0.02 \\
\hline
\end{tabular}

TABLE 2

Trace element data for representative groundwater samples from the Wassa West District

\begin{tabular}{|c|c|c|c|c|c|c|c|c|c|c|c|c|}
\hline urce & BH No. & $H g$ & As & $B$ & $B a$ & $\mathrm{Cr}$ & $M n$ & $\mathrm{Fe}$ & $\mathrm{Ni}$ & $\mathrm{Cu}$ & $Z n$ & $\mathrm{Se}$ \\
\hline estea & $\operatorname{vcc}(13)$ & 025 & 0820.002 & & 028 & 04 & & 0.431 & & & 20.120 & 0.0120. \\
\hline Prestea & wcc (12) & .016 & 0340.002 & 9 & 027 & 0.002 & 0.233 & 2.510 & 0.028 & 0.024 & 0.080 & 0.0040 \\
\hline lemang & $0-13-65-4$ & 0.012 & 0.0360 .002 & 0.044 & 0.041 & 0.002 & 0.293 & 0.007 & 0.012 & 0.024 & + 0.034 & $\begin{array}{ll}0.011 & 0.001\end{array}$ \\
\hline nkobra & $\mathrm{B} / 065-2$ & .018 & 0.0390 .009 & .035 & 0.037 & 0.002 & 0.266 & 3.810 & 0.009 & 0.002 & 0.030 & 0.0170 .001 \\
\hline Ankobra & $/ 065$ & 3 & 0.0330 .004 & 2 & 0 & 0.002 & 0.442 & 13.10 & 26 & 0 & 0 & 000. \\
\hline Kwame Nirmpa & $1-2$ & 25 & .0510 .001 & & & 0.003 & 1.110 & & & 0.026 & 36 & 0.0000 \\
\hline Odumase & $4-\mathrm{I}-45-1$ & 0.026 & 0.0300 .000 & & 0.055 & 0.001 & 0.219 & & 0.000 & 0.002 & 0.016 & $\begin{array}{lll}0.001 & 0.001\end{array}$ \\
\hline Odumase & -4 & 0.014 & 2.0400 .004 & 0.041 & 0.377 & 0.002 & 0.281 & 1.040 & 0.088 & 0.108 & 0.189 & 0.0250 .022 \\
\hline Odumase & 00 & 0.012 & 0.0370 .039 & 7 & 0.0 & 0.002 & 0.141 & 7.090 & & 0.001 & 0.041 & 0.0210 .001 \\
\hline Beposo & $4-$ & 0.0 & 10.002 & & 0. & 0.002 & 0.358 & & & 0. & & 050.000 \\
\hline Beposo & 4 & $0 .($ & 0.2360 .004 & 3 & 0 . & 0.002 & 0.930 & 10.90 & & 0.003 & 33 & 000.002 \\
\hline aus & & & $\begin{array}{lll}0.159 & 0.008\end{array}$ & & & 0.001 & 0.056 & & & & & 0.0000 .001 \\
\hline Bogo & 1 & 6 & 70.004 & 9 & 0.0 & 0.001 & 0.458 & & 0. & 0.004 & +0.033 & 0.0100 .002 \\
\hline Insu & 1 & 2 & 0.0400 .000 & $O G$ & 0.1 & 0.001 & 0.066 & 0.026 & 0. & 0.019 & 0.014 & 0.0000 .001 \\
\hline asu & & & & & & 0.002 & 0.516 & & & & & 0.0000 .001 \\
\hline Huni Valley & N 121 & 0.014 & 0.2530 .000 & . & 0. & 0.000 & 0.410 & 48 & 0.003 & 0.007 & 0.058 & 0.0000 .003 \\
\hline Nsuem & C1/D/0901 & & 0.0360 .000 & & 0. & 0.001 & 1.070 & & & 0.004 & 0.025 & $\begin{array}{lll}0.001 & 0.001\end{array}$ \\
\hline eboanda & $1 / \mathrm{H} / 0041$ & 0.016 & 0.0340 .000 & 2 & 0.2 & 0.001 & 0.488 & 1.040 & 0.014 & 0.001 & 0.032 & $\begin{array}{lll}0.011 & 0.001\end{array}$ \\
\hline Atw & /UU & & 0.0400 .000 & & & 0.002 & 0.399 & & & & 0.020 & 0.0000 .001 \\
\hline Tarkwa Sec. Sch & DO & & 0.1070 .001 & & & 0.002 & 1.510 & & & & & 0.0090 .001 \\
\hline Tamso & $20-$ & 0.013 & 0.6980 .001 & 0 & 0.0 & 0.003 & 0.399 & 0.087 & 0.012 & 0.006 & 0.055 & 0.0000 .002 \\
\hline Tamso & $20-1$ & 0.023 & 1.1200 .000 & 0.0 & 0.141 & 0.002 & 0.597 & 0.001 & 0.012 & 0.015 & 0.044 & 0.0010 .004 \\
\hline Benso & 21-E-13-4 & 0.024 & 0.0570 .000 & 0.0 & 0.0 & 0.003 & 0.356 & 0.027 & 0.011 & 0.131 & 0.088 & $\begin{array}{lll}0.002 & 0.011\end{array}$ \\
\hline Benso & & & 0.0820 .000 & & 0.0 & 0.002 & 0.050 & & & & & 0.0000 .007 \\
\hline Nsuaem & & 0.012 & 0.0690 .000 & & 0.0 & 0.004 & 0.007 & 0.069 & & 0.016 & 0.031 & $0.000 \quad 0.007$ \\
\hline impa & 18-E-77-3 & 0.014 & 0.1140 .004 & 0.033 & 0.371 & 0.002 & 1.340 & 9.810 & 0.010 & 0.002 & 10.400 & 0.0150 .002 \\
\hline
\end{tabular}

Additionally, acidity gives sour taste to water. For the reason of taste, the WHO (1993) limits the $p \mathrm{H}$ range for water potability to 6.5-8.5. Consequently, as can be seen from Table 1 , the $p \mathrm{H}$ values for more than $90 \%$ of the boreholes and wells within the Wassa West District are outside this range suggesting that most of the wells have potential taste problem. Electrical conductivity values are low, in the range of 37-780 $\mu \mathrm{S} \mathrm{cm}^{-1}$ [total dissolved solids (TDS) range 23.7-499.2 $\mu \mathrm{g}$ $1^{1}{ }^{1}$ with a mean value of $246.4 \mu \mathrm{S} \mathrm{cm}-^{-1}\left(\mathrm{TDS}=157.7 \mathrm{mg} \mathrm{l}^{-1}\right)$ indicating that the groundwaters are generally fresh. Davis \& DeWiest (1966), WHO (1980) and WHO (1993) regard groundwater as fresh water if the groundwater TDS value is less than $1000 \mathrm{mg} \mathrm{l}^{-1}$.

Total hardness is an important criterion for ascertaining the suitability of water for domestic, drinking and many industrial uses (Karanth, 1994). In this paper the hardness criterion is used exclusively for determining the usability of the wells for domestic and drinking purposes only. Hardness of water for domestic use relates mainly to its reaction with soap. Since soap is precipitated principally by $\mathrm{Ca}^{2+}$ and $\mathrm{Mg}^{2+}$, hardness is defined as the sum of the concentrations of these ions expressed as $\mathrm{mg} \mathrm{l}^{-1}$ of $\mathrm{CaCO}_{3}$. Water with hardness in the range $0-60 \mathrm{mg} \mathrm{l}^{-1}, 61-120 \mathrm{mg} \mathrm{l-}{ }^{1}$, 
121-180 $\mathrm{mg} \mathrm{l}^{1^{-1}}$ and $>180 \mathrm{mg} \mathrm{l}^{1-}$ are regarded as soft, moderately hard, hard and very hard, respectively (Hem, 1970). Groundwaters from the Wassa West District vary largely in total hardness from $10 \mathrm{mg} \mathrm{l}^{-1}$ to $358 \mathrm{mg} \mathrm{l}^{-1}$. Generally, the waters are moderately hard to very hard with only $40 \%$ of the boreholes having soft water. The hardness of the groundwaters is derived mainly from carbonate sources since alkalinity values have exceeded the total hardness in most cases.

The use of the groundwaters for domestic purposes may, therefore, lead to soap wastage or more soap requirement for washing. Contrary to the negative perception of domestic usage of hard water, recent studies have shown that coronary heart diseases are less common in areas of hard water than in areas of soft water (Crawford, 1972). Nonetheless, Neri et al. (1975) observed low incidence of coronary heart diseases in areas of soft waters and postulated that very soft waters being low in ionic concentration would not contain enough toxic substances to increase mortality. On the contrary, hard waters being high in ionic concentration would contain more toxic substances but also enough benign minerals to block and overcome their toxic effects. Thus, the hardness of the water in the wells within the Wassa West District is beneficial for drinking purposes in that the waters may have enough propitious substances that can neutralize other substances harmful to human health.

\section{Inorganic substances}

Major ions, principally $\mathrm{Na}^{+}, \mathrm{K}^{+}, \mathrm{Ca}^{2+}, \mathrm{Mg}^{2+}, \mathrm{HCO}_{3}^{-}, \mathrm{Cl}-, \mathrm{SO}_{4}^{2}-, \mathrm{Si}$, and minor ions such as $\mathrm{NO}_{3}^{-}$ , F-, $\mathrm{Fe}$, and $\mathrm{Mn}^{2+}$, as well as trace elements $\mathrm{Zn}, \mathrm{Cu}, \mathrm{I}^{-}, \mathrm{F}^{-}, \mathrm{V}, \mathrm{Se}, \mathrm{Co}, \mathrm{Ni}, \mathrm{Cr}, \mathrm{Mo}$ and $\mathrm{P}$ are generally essential for human health and metabolism (Safe Drinking Water Comm., 1980). However, if some of these substances particularly the minor and trace elements occur in the water above certain limits, they become hazardous to health or impact sensory effect to the water that makes it objectionable to the consumer. Table 3 presents two lists of chemical substances. The list A comprises chemical substances that are of health significance in drinking water while B consists of substances which, although not necessarily harmful to health, may give rise to complaints from consumers because of the aesthetic effect they produce in the water.

TABLE 3

The range and mean values of inorganic constituents in the groundwaters of the Wassa West District and the WHO (1993) drinking water quality guideline values

Wassa West District groundwaters

Range of values

Antimony $(\mathrm{Sb})$

Arsenic (As)

Barium (Ba)

Beryllium (Be)

Boron (B)

Cadmium (Cd)

Chromium $(\mathrm{Cr})$

Copper $(\mathrm{Cu})$

Fluoride (F)

Lead $(\mathrm{Pb})$

Manganese (Mn)

Mercury (Hg)

Molybdenum (Mo)

Nickel (Ni)

Nitrate $\left(\mathrm{NO}_{3}\right)$

Selenium (Se)

Uranium (U)
Mean Values

WHO (1993)

Guideline maximum value

$\begin{array}{llc}0.0-0.001 & 0.0 & 0.005(\mathrm{P}) \\ 0.0-0.046 & 0.002 & 0.01(\mathrm{P}) \\ 0.03-0.70 & 0.118 & 0.7 \\ & & \text { NAD } \\ 0.0-0.3 & 0.009 & 0.3 \\ 0.0-0.003 & 0.0 & 0.003 \\ 0.0-0.066 & 0.004 & 0.05(\mathrm{P}) \\ 0.0-0.211 & 0.013 & 2(\mathrm{P}) \\ & & 1.5 \\ 0.0-0.026 & 0.002 & 0.01 \\ 0.006-1.3 & 0.298 & 0.5(\mathrm{P}) \\ 0.0-0.037 & 0.018 & 0.001 \\ 0.0-0.07 & 0.0 & 0.07 \\ 0.0-0.076 & 0.009 & 0.02 \\ 0.0-27.0 & 5.0 & 50 \\ 0.0-0.017 & 0.003 & 0.01 \\ & & \mathrm{NAD}\end{array}$


$B$

$\begin{array}{lccc}\text { Aluminium }(\mathrm{Al}) & 0.0-2.51 & 0.084 & 0.2 \\ \text { Ammonia }\left(\mathrm{NH}_{4}\right) & & & 1.5 \\ \text { Chloride }(\mathrm{Cl}) & 4.5-194.0 & 27.3 & 250 \\ \text { Sulphide }\left(\mathrm{H}_{2} \mathrm{~S}\right) & & & 0.05 \\ \text { Iron }(\mathrm{Fe}) & 0.0-18.3 & 1.52 & 0.3 \\ \text { Sodium }(\mathrm{Na}) & 0.7-41.9 & 17.9 & 200 \\ \text { Sulphate }\left(\mathrm{SO}_{4}\right) & 4.5-20.3 & 13.9 & 250 \\ \text { Zinc } & 0.0-12.4 & & 3.0\end{array}$

All values are in milligrams per litre.

P: provisional guideline value

Table A lists those chemicals of health significance in drinking water.

Table B lists substances in drinking water, which although not necessarily harmful to health, may give rise to complaints from consumers.

NAD: No adequate data

\section{Major ions}

Major ions for which recommended permissible limits are available and contained in the B list of Table 3 are sodium, sulphate and chloride. As indicated in the previous paragraph, intake by humans of water with concentrations of these ions above the recommended limits is generally not harmful (Freeze \& Cherry, 1979). When $\mathrm{Na}^{+}$exceeds the recommended limit of $200 \mathrm{mg} \mathrm{l}^{-1}$, the water tastes salty. Similarly, maximum chloride concentration permissible in drinking water is $250 \mathrm{mg} 1-^{-1}$ primarily because of taste. Likewise, sulphate concentration in drinking water must not exceed $250 \mathrm{mg} \mathrm{1-1}$ otherwise the water will taste bitter. Higher $\mathrm{SO}_{4}^{2}$ - concentrations can even produce laxative effect. It is noticeable from Table 3 that the major constituents $\mathrm{Na}^{+}, \mathrm{Cl}^{-}$and $\mathrm{SO}_{4}{ }^{2-}$ are generally low and well below the WHO (1993) recommended guideline maximum values for water potability. They, therefore, pose neither physiological nor aesthetic problem to groundwater usage for drinking or domestic purposes within the Wassa West District. Thus, with respect to major ions, the groundwater quality in the Wassa West District is excellent.

\section{Minor inorganic ions}

The minor ions under consideration in this paper are those included in the list A - boron, fluoride, nitrate, and list B - iron. Boron is harmful to human health if its concentration exceeds $0.3 \mathrm{mg} \mathrm{l-}{ }^{-1}$. The concentration range of boron in the wells within the Wassa West District is 0.0-

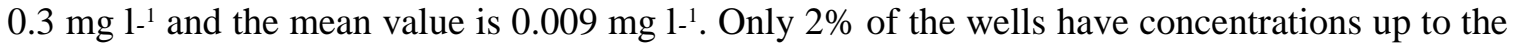
maximum permissible value. Boron, therefore, poses little or no quality problem to groundwater usage for drinking purposes in the Wassa West District.

Fluoride in drinking water is beneficial to human health in that it reduces tooth decay. At high concentrations, however, it results in the molting of teeth (fluorosis) and skeletal fluorosis. The maximum permissible F- concentration in drinking water is $1.5 \mathrm{mg} 1^{-1}$ (WHO, 1993). As indicated in Tables 2 and 3, the fluoride concentrations in the boreholes and wells within the District is universally low and mostly below the beneficial range $\left(0.3-1.5 \mathrm{mg} \mathrm{l}^{1}\right)$ for human health. Thus, additional fluoride requirement of the people living in the District should be sought from other sources, for example, from toothpaste to prevent high incidence dental caries. On the other hand, the risk of dental or skeletal fluorosis as a result of drinking from groundwater sources is not likely to occur in the District.

The maximum permissible concentration of $\mathrm{NO}_{3}^{-}$in drinking water is $50.0 \mathrm{mg} \mathrm{l}^{-1}$. Higher nitrate levels is detrimental to young infants, particularly those under 4 months, as they could suffer from methemo-globinemia (blue baby disease). Additionally, though adults can absorb 
higher dosages of nitrate, nitrate is known to play a role in the production of nitrosamines (known carcinogens) in the stomach (Wolff \& Wasserman, 1972). Hill et al. (1973) assign high nitrate intake as a possible reason for higher death rate from gastric cancer in communities that had high nitrates level in their drinking water. Values of nitrate concentration in the groundwaters of the District, as can be observed from Tables 1 and 2, are far below the maximum permissible limit. Thus, the threat to health from methemoglobinemia and nitrosamines is very low.

Iron is essential to the human body and its intake through drinking water is normally an insignificant portion of the body requirement (Freeze \& Cherry, 1979). The common form of iron in the $p \mathrm{H}$ range for the groundwaters in the District is the soluble ferrous ion $\left(\mathrm{Fe}^{2+}\right)$. When exposed to the atmosphere, $\mathrm{Fe}^{2+}$ is oxidised to $\mathrm{Fe}^{3+}$. In this state it hydrolyses and precipitates as ferric hydroxide, causing a brown discolouration of the water and the characteristic brown stains in sinks and laundered textiles. In addition, $\mathrm{Fe}^{3+}$ imparts metallic taste to the water. The maximum permissible concentration of $0.3 \mathrm{mg} \mathrm{l}^{-1}$ (WHO, 1993) in drinking water is primarily for reasons of taste and avoidance of staining of sinks and laundered textiles. However, an upper limit of $1.0 \mathrm{mg}$ $1^{-1}$ should suffice for most purposes (WHO, 1993).

Iron apparently is the most problematic minor ion associated with the groundwaters in the Wassa West District. Approximately $40 \%$ of boreholes and wells within the District have total iron concentrations greater than $1.0 \mathrm{mg} \mathrm{l}^{-1}$. The incidence of high iron concentration in boreholes may result in complain from people using the boreholes that may ultimately lead to low patronage or total rejection of some of the boreholes. Thus, if boreholes are to be relied on for potable water supply as currently practised, then there is the need to build simple aerators or iron removal plant attached to some selected boreholes, particularly those forming the $40 \%$.

\section{Trace elements}

Contrary to expectation from a mining area, trace metal loading of the groundwaters in the Wassa West District is rather low. Aluminum, manganese and mercury are the only trace metals that occur in relatively high concentrations in a significant percentage of the boreholes or wells. Arsenic, barium, lead, nickel, selenium and zinc occur in concentrations a little higher than the WHO (1993) maximum guideline limits and in only a few of the boreholes or wells. The rest of the trace elements only occur in very minute concentration, close to their detection limits.

Aluminium $\left(\mathrm{Al}^{3+}\right)$ appears to have only little deleterious effect on humans. Nonetheless, aluminium toxicity has been associated with central nervous system disorders including Alzheimer's disease and dialysis dementia (Moskowitz et al., 1986; Monier-Williams, 1935). However, the greatest problem associated with the metal is the discolouration it produces in drinking water and its distribution systems. This increases when aluminium concentration exceeds $0.2 \mathrm{mg} \mathrm{l}^{-1}$ in the water and makes the water aesthetically unacceptable (WHO, 1993).

In the Wassa West District, $\mathrm{Al}^{3+}$ ion concentration in the groundwaters is in the range 0.0-2.5 $\mathrm{mg} \mathrm{l^{-1 }}$ with a mean of $0.19 \mathrm{mg} \mathrm{l}^{-1}$. As expected, the high $\mathrm{Al}^{3+}$ ion concentrations are associated with boreholes with lower $p \mathrm{H}$ values. For instance, the borehole at Odumase with the identification number 44-I-45-4 has the lowest mean $p \mathrm{H}$ value of 3.89 and the highest concentration of $\mathrm{Al}^{3+}$ ions of $2.51 \mathrm{mg} \mathrm{l}^{-1}$. Similarly Tamso (20-I-89-1) has a mean $\mathrm{pH}$ and $\mathrm{Al}^{3+}$ ion concentration of 3.94 and $1.28 \mathrm{mg} \mathrm{l}^{-1}$, respectively. The aluminium concentration in the groundwaters within the District appears to pose quality problem to borehole water supply since approximately $20 \%$ of the boreholes exceed the WHO, 1993 permissible limit for water potability.

Similar to iron, the common form of manganese in the groundwaters in the Wassa West District under the existing $p \mathrm{H}$-Eh conditions is the soluble manganous ion, $\mathrm{Mn}^{2+}$. On exposure to the atmosphere, $\mathrm{Mn}^{2+}$ is oxidised to much less soluble hydrated oxide. The hydrated oxide forms black stain in sinks and also stain laundered textiles. Additionally, the growth of certain 
problematic bacteria that concentrate manganese and give rise to taste, odour and turbidity problems in the distributed water is also supported by manganese (Griffin, 1960; Wolfe, 1960).

Manganese is a vital micronutrient for both plants and animals but when taken in very large doses can cause some diseases and liver damage (Wolfe, 1960). In small doses, manganese has only little physiological effect; nonetheless, as in the case of iron, the sensory effect that it produces may lead to the rejection of the borehole. It is for this reason that WHO (1993) has given guideline limit for water potability with respect to manganese as $0.5 \mathrm{mg} \mathrm{l}^{-1}$. The concentration of manganese in the groundwaters in the District varies between $0.002 \mathrm{mg}^{-1}$ and $2.410 \mathrm{mg} \mathrm{l}^{-1}$ with a mean value of $0.329 \mathrm{mg} \mathrm{l}^{-1}$.

Manganese occurs in concentrations greater that $0.5 \mathrm{mg} \mathrm{l}^{-1}$ in approximately $25 \%$ of the boreholes and wells within the Wassa West District. The percentage is high enough to affect the patronage of boreholes and wells that have been provided at great cost. There is, therefore, the need to remove manganese from the water. Building iron removal plant to be attached to the boreholes may be a possible solution to the manganese problem, since most of the wells that have high iron content incidentally also have high manganese content. The ferric hydroxide formed in the iron removal plant during aeration has the capacity to absorb manganous ions, and, hence, the dual removal of both iron and manganese.

The WHO (1993) permissible guideline limit for mercury concentration in potable water is $0.001 \mathrm{mg} \mathrm{l}^{-1}$. In the Wassa West District, the concentration of mercury in groundwaters varies within the range $0.0-0.038 \mathrm{mg} \mathrm{l}^{-1}$ (Tables 2 and 3). However, mercury has not been detected in any of the rocks within the Prestea-Tarkwa area; neither are there other industries in the area apart from mining that can release mercury in significant quantity to the environment. Furthermore, the high concentration of mercury has only been detected in the boreholes during the rainy season whereas during the dry season, concentrations were merely around detection limit. This apparently suggests that mercury concentration in the wells is related to the recharge regimes of polluted surface water into the groundwater system. This is likely to occur during the wet season than in the dry season where mining pits and ponds used for washing gold by small-scale (legalised and illegalised) miners are flooded. Run off and floodwaters containing remnants of mercury recharge aquifers. In the dry season, on the contrary, seepage from ponds used for washing gold can hardly infiltrate into the aquifers.

Oral ingestion of inorganic mercury is rapidly accumulated in the kidney and it is very irritating to the gastrointestinal tract and can cause nausea, vomiting, pain, ulceration, diarrhoea and kidney damage, including kidney failure (WHO, 1980). Toxicity to the brain and nervous system has been reported following large doses of inorganic mercury taken medicinally (WHO, 1980). Consequently, mercury poses the most physiological problem associated with groundwater for drinking purposes. People living in the Wassa West District are potentially exposed to the danger of diseases associated with oral ingestion of inorganic mercury. There is, therefore, the need to control the usage of mercury in the environment.

The International Agency for Research on Cancer, the WHO and the US-EPA classify arsenic (As) as a known carcinogen (an agent producing and exciting cancer) and a toxin (Smedley et al., 1995). Arsenic taken in large doses produces death from fluid loss and circulatory collapse (Carlos et al., 1997). Small oral doses of arsenic produce gastro-intestinal pains, haemorrhage, nausea, vomiting, diarrhoea, anaemia, and neurological toxicity such as headache, lethargy, confusion, hallucination, seizures, and coma. Long term low-level exposure to arsenic may result in cardiovascular toxicity, anaemia, liver toxicity, and a pattern of skin changes that includes darkening of the skin and the appearance of small corns or warts (Carlos et al., 1997). Skin cancer has been associated with long-term, low-level exposure to arsenic through drinking water (WHO, 1993), and there is suggestive evidence of increasing risk of bladder, kidney, liver and lung tumours as well. Based on its carcinogenicity, and taking into consideration its potential nutrient 
requirements, WHO (1993) restricts the level of arsenic in drinking water provisionally to 0.01 mg l-1.

The concentration of arsenic in the groundwaters of the Wassa West District is very low and varies from $0.0 \mathrm{mg} \mathrm{l}^{-1}$ to $0.049 \mathrm{mg} 1^{-1}$ with a mean value of $0.003 \mathrm{mg} \mathrm{l}^{-1}$ (Table 3). The very low concentration of arsenic in the shallow groundwaters in spite of the high presence of arsenopyrite in association with the gold ore in the District suggests a level of co-precipitation of arsenic with ferric oxyhydroxide in the creeks and the unsaturated zone before possible infiltration into the aquifer. Only approximately $5 \%$ of the wells and boreholes have arsenic concentration slightly in excess of the WHO (1993) guideline limit of $0.01 \mathrm{mg} \mathrm{l}^{-1}$ (Table 3). These wells are mainly located in the neighbourhood of Bogoso and Prestea.

Since only $5 \%$ of the wells and boreholes have arsenic concentration slightly in excess of the WHO (1993) limit, and all the wells are incidentally situated around the Bogoso-Prestea neighbourhood, arsenic poses only a minor problem to using groundwater for drinking purposes in the District. Only people living in communities in the Bogoso-Prestea area appear to be potentially at risk of diseases associated with long-term low-level exposure. However, Wang \& Huang (1994) noted that no morbidity cases were found where arsenic concentrations of drinking water were less than $0.1 \mathrm{mg} \mathrm{l}^{-1}$ but morbidity increased exponentially as aqueous As increased and mild As poisoning was observed in the range $0.1-0.2 \mathrm{mg} \mathrm{1-}{ }^{1}$. Arsenic concentration in any individual borehole or well in the District, as can be seen from Tables 2 and 3, rarely exceeded $0.05 \mathrm{mg} \mathrm{l}^{-1}{ }^{1}$ suggesting that despite exceeding the WHO (1993) permissible guideline limit, no morbidity problem from elevated arsenic concentration is expected when the groundwater is used for drinking purposes.

The WHO (1993) recommended limit of barium for potable water is $0.7 \mathrm{mg} \mathrm{l}^{-1}$ (Table 3). Barium concentrations in water higher than the WHO (1993) value may result in symptoms of gastrointestinal tract, vomiting and diarrhoea, and breakdown of the central nervous system, causing violent tonic and chronic spasms followed in some cases by paralysis (Browning, 1961; Patty, 1962). The concentration of barium in the groundwaters from the District is generally lower than the WHO guideline value for potability. Barium concentration in the groundwaters of the District, therefore, does not pose a threat to groundwater development.

Lead may occur in association with sulphides. In the Wassa West District, lead occurs in association with the sulphide ores in the form of boulangerite $\left[\left(\mathrm{Pb}_{5} \mathrm{Sb}_{4} \mathrm{~S}_{11}\right)=0.01 \%\right]$, bournonite $\left[\left(\mathrm{PbCuSbS}_{3}\right)=0.02 \%\right]$, galena $[(\mathrm{PbS})=0.006 \%]$ (Owusu-Ansah, 2000, personnal communication). High lead concentrations result in metabolic poisoning that manifest in symptoms such as tiredness, lassitude, slight abdominal discomfort, irritation, anaemia and, in the case of children, behavioural changes (WHO, 1980). The WHO (1993) recommended guideline limit for lead level for water potability is $0.01 \mathrm{mg} 1-^{1}$. Approximately $9 \%$ of the boreholes in the District have lead levels slightly higher than WHO (1993) recommended guideline limit (Table 3 ). The relatively high lead concentrated waters occur in the Bogoso-Prestea area. Thus, people living around this area are potentially at risk of metabolic poisoning. Children under 5 years, and pregnant women are particularly at potential risk of elevated lead levels in the blood stream (Moskowitz et al., 1986). Nonetheless, the lead levels are only slightly above the recommended limit and should not cause alarm.

Nickel was considered to be relatively non-toxic to man but recent studies support the potential carcinogenicity to humans and animals of several nickel compounds under certain exposure conditions (Carlos et al., 1997). Although nickel compounds have not been identified to be carcinogenic in either humans or animals following ingestion, gastrointestinal distress has been reported in workers who drank water contaminated with high levels of nickel (Carlos et al., 1997). Most of the nickel in drinking water comes from water distribution systems and is generally less than $10 \mu \mathrm{g} / \mathrm{l}(\mathrm{WHO}, 1980)$. The WHO (1993) recommends that the level of nickel 
in drinking or potable water should not exceed $0.02 \mathrm{mg} \mathrm{l}^{-1}$. Approximately $3 \%$ of the boreholes in the Wassa West District have nickel concentration slightly in excess of the WHO recommended limit of $0.02 \mathrm{mg} \mathrm{l}^{-1}$. Nickel does not, therefore, appear to pose a threat to groundwater development in the Tarkwa-Prestea area.

Selenium is biologically beneficial to the metabolic requirement of animals when taken in the concentration range of $0.1-10 \mathrm{mg} \mathrm{kg}^{-1}$ of food. Selenium is, however, considered toxic to man and symptoms associated to selenium toxicity are similar to those of arsenic (Fairhill, 1941). Selenium concentrations in the District are in the range $0.0-0.017 \mathrm{mg} \mathrm{l}^{-1}$, and only about $3 \%$ of the boreholes and wells have selenium concentration above WHO recommended limit of $0.01 \mathrm{mg}$ $1-^{1}$. Thus, selenium does not pose major threat to groundwater development in the District.

Zinc occurs as a natural mineral in many drinking waters and is an essential dietary nutrient and a beneficial element in human metabolism (Vallee, 1957). Inadequate dietary zinc intake can lead to appetite loss, poor growth and development, birth defects, slow wound healing and skin lesions. Too much zinc (at least 10 times the recommended daily dose) can produce gastrointestinal disturbances such as pain, cramping, nausea and vomiting, diarrhoea and pancreatic toxicity. Long-term ingestion of zinc compounds at lower doses has led to copper deficiency by interfering with the body's ability to take in and use copper (Carlos et al., 1997). Excess zinc also produces aesthetic effect (metallic taste) on the water for which reason the WHO (1993) recommended a limit of $3.0 \mathrm{mg} \mathrm{l}^{-1}$ for potable water. Zinc concentration in the groundwaters of Wassa West District exceeded WHO recommended limit in only $1 \%$ of the boreholes. Thus, zinc concentration does not pose quality problem for groundwater supply and development in the Wassa West District.

The concentration of copper is above detection but it has not exceeded the provisional WHO recommended limit of $2.0 \mathrm{mg} \mathrm{l}^{-1}$ for water potability in any of the hand-dug wells or boreholes within the Tarkwa-Prestea area. The remaining trace metals, as mentioned earlier, only occur in very minute concentrations or below detection and, therefore, pose neither physiological nor aesthetic problems to groundwater quality in the Wassa West District.

\section{Conclusion}

The major ions in the groundwater in the Wassa West District are generally low and do not pose any quality problem for their use as drinking water. The groundwaters are moderately hard to very hard and their usage for washing may result in soap wastage. However, hard waters are known to have enough benign substances that can offset the negative effect of some minor and trace elements that may exist in the groundwaters. Despite the generally low minor and trace elements loading, potential major quality problems exist with regards to the concentration of some of them. Mercury concentration in the wells during the rainy season by far poses the greatest physiological problems as it is above the WHO recommended concentration limit in most wells. This problem seems to be anthropogenic in origin and can be reduced by limiting the spillage of the chemical in the environment. The concentrations of iron, manganese and aluminium also pose potential sensory problem for the use of the groundwaters for domestic purposes. However, the use of iron removal plants or simple aerators can help in reducing the excess trace elements concentrations from the water by inducing co-precipitation of the trace elements with $\mathrm{Fe}$-oxyhydroxides.

\section{Acknowledgement}

The Danish International Development Authority (DANIDA), through Grant No. Dau. 81/ 300, funded the data collection for the study. The author is grateful to Prof. Niels Oluf Jørgensen for getting the trace elements analyses carried out at the Geological Institute of the University of 
Copenhagen. The major ions analysis was carried out in the Ecological Laboratory, University of Ghana.

\section{References}

Acquah P. C. (1992). Emerging trends in gold processing and some related environmental issues in Ghana. Regional Trends in African Geology. Proceedings of the 9th International Geological Conference (Accra, 2-7 November 1992. Geological Society of Africa.

Appiah H., Norman D. I., Kuma J. S., Nartey R. S. and Dankwa J. B. K. (1992). Sources of diamond in the Bonsa field. Regional Trends in African Geology. Proceedings of the 9th International Geological Conference (Accra, 2-7 November 1992. Geological Society of Africa.

Agyapong W. A., Amanor J. A. and Acheampong E. O. (1992). Selective open pit gold mining at Ashanti Goldfields, Obuasi, Ghana. Regional Trends in African Geology. Proceedings of the 9th International Geological Conferenc Accra, 2-7th November 1992. Geological Society of Africa.

Barcelona M., Gibbs J. P., Helfrich J. A. and Garske E. E. (1985). Practical guide for groundwater sampling. Illinois State Water Survey ISWS Contract Report 374.

Browning E. (1961). Toxicity of industrial metals. Butterworth, London.

Carlos D., Da Rosa J. D., Lyon J. S., Udall S. L. and Hocker P. M., (1997). Golden Dreams, Poisoned Streams. Mineral Policy Center. Washington D. C.

Claasen, H. C. (1982). Guidelines and techniques for obtaining water samples that accurately represent the water quality for an aquifer. U.S. Geological Survey Open File Report 82-1024. 49 pp.

Crawford M. D. (1972). Hardness of drinking water and cardiovascular disease. Proc. Nutr. Soc. 31: 347-353.

Davis S. N. and DeWiest R. J. M. (1966). Hydrology. John Wiley \& Sons, Inc., New York. 463 pp.

Dickson K. B. and Benneh G. (1980). A New Geography of Ghana, Longmans Group Limited, London.

Fairhill L. T. (1941). Toxic contaminant of drinking water. J. N. E. Wat. Wks Ass. 55: 400.

Freeze A. R. and Cherry J. A. (1979). Groundwater. Prentice-Hall Inc., Englewood Cliffs, New Jersey 07632.

Griffin A. E. (1960). Significance and removal of manganese in water supplies. J. Am. Wat. Wks Ass. 52: 1326.

Hem J. D. (1970). Study and interpretation of the chemical characteristic of natural water, 2 edn. U.S. Geol. Survey Water Supply Paper 1473. 363 pp.

Hill M. J., Hawksworth G. and Tattersall G. (1973). Bacteria, nitrosamines, and cancer of the stomach. Br. J. Cancer 28: $562-567$.

Hounslow A. W. (1995). Water Quality Data Analysis and Interpretation. Lewis Publishers, Boca Raton, New York.

Junner N. R., Hirst T. and Service H. (1942). Tarkwa Goldfield. Memoir No.6. Gold Coast Geological Survey.

Karanth K. R. (1994). Groundwater Assessment Development and Management. Tata McGraw-Hill Publishing Company Limited, New Delhi.

Langmuir D. (1997). Aqueous Environmental Geochemistry. Prentice Hall Upper Saddle River, New Jersey 07458.

Monier-Williams G. W. (1935). Aluminium in Food. Ministry of Health, London.

Moskowitz P. D., Coveney E. A., Hamilton L. D., Kaplan E. and Medeiros W. H. (1986). Identifying human population at risk from acid deposition mobilised materials in drinking water supplies: A preliminary pilot study. Acid precipitation and health -part 1. Wat. Qual. Bull.

Neri L. C., Hewitt D., Schreiber G. B., Andersen T. W., Mandel J. S. and Zdrojewski A. (1975). Health aspect of hard and soft waters. J. Am. Wat. Wks Ass. 67: 403-409.

Patty F. A. (1962). Industrial hygiene and toxicology, Vol. II. John A. Wiley, New York. pp. 998-1002.

Smedley P. L., Edmunds W. M., West J. M., Gardner S. J. and Pelig-BA K. B. (1995). Vulnerability of Shallow Groundwater Quality due to Natural Geochemical Environment. Health problems related to groundwater inn the Obuasi and Bolgatanga areas, Ghana. Report prepared for ODA under the ODA/BGS Technology Development and Research Programme. Project 92/5.

Safe Drinking Water Comm., (1980). Drinking water and health, Vol. 3. Nat. Acad. Press, Washington. 415 pp.

Vallee B. L. (1957). Zinc and its biological significance. Arch. Industrial. Health 16: 147.

Wang L. \& Huang J. (1994). Chronic arsenism from drinking water in some areas of Xinjiang, China. In Arsenic in the environment, Part II: Human health and ecosystem effects. (G. O. Ntiagu, ed.) Wiley, New York.

Wilson F. H. and Hawkins D. B. (1978). Arsenic in streams, stream sediments and ground water; Fairbanks area, Alaska. Envir. Geol. 2: 195-202.

William M. W. and Smith B. (1994). Empirical and modelled hydrochemistry of acid mine drainage, Iron Duke mine, Mazowe, Zimbabwe. British Geological Survey Technical Report WC/94/78/R.

Woiff I. A. and Wasserman A. E. (1972). Nitrates, nitrites, and nitrosamines. Science 177: 15-19.

World Health Organisation (WHO) (1980). Recommended health-based limits in occupational exposure to trace metals. Technical Report Series, No. 647. Vienna, Austria. 
World Health Organisation (WHO) (1993). Guidelines for drinking water quality. Revision of the 1984 guidelines. Final task group meeting. Geneva, 21-25 September 1992.

Wolfe R. S. (1960). Microbial concentration of iron and manganese in water with low concentrations of these elements. J. Am. Wat. Wks Ass. 52: 1335.

WRRI (1986). Effect of mining activities on River Ankobra and its tributaries. Unpublished Water Resources Research Institute's technical publication. 